\title{
Designing Training and Development Model Based on Socialpreneurship to Create Sustainable Competitiveness for Employee in National Fisheries Sector
}

\author{
Lindawati Kartika
}

Lecturer at Department of Management, Faculty of Economic and Management Bogor Agricultural University; lindawati.kartika@gmail.com

Fety Nurlia Muzayanah

Student at Magister Science of Management, Department of Management, Faculty of Economic and Management Bogor Agricultural University; fetynurlia@gmail.com

Doi:10.5901/mjss.2015.v6n5s5p142

\section{Abstract}

\begin{abstract}
The aims of this study were: (1) to identify the main factors which causing suboptimal employee performance and productivity in contributing the number of entrepreneurs in Indonesia and (2) Formulating Strategy to enhance Employee competencybased on socialpreneurship in order to create sustainable fisheries and marine competitiveness. Method of data analysis using Fishbone analysis, SWOT analysis and The House models. Based on the result of this study there were two main factors which causing suboptimal model of developing competency of employee in the field of fisheries which consists of internal factors related to the mindset of employee to pursue a career as the highest comfort zone and work satisfaction but specifically did not have an impact on social welfare, however the main external factors caused by supervision model of training and development in order to create employee competency was not based on outcome also without continuous improvement in monitoring and evaluation. Moreover the best Strategy to enhance competence-based on socialpreneurship pillar through the house model is formulating training and development which has the following outcomes: Increased healthcare and caregiver demand, Youth employability, Academic Recognition, Reduced Government Expenditures, global entrepreneurship Increased the index for Indonesia and Healthy Lifestyles, involving academic, community Small and medium Enterprises in order to optimizing the strategic role function of Pusat Pelatihan Mandiri Kelautandan Perikanan (P2MKP) through survey activity, shaping and training modules which evaluated as ongoing basis.
\end{abstract}

Keywords: socialpreneurship, sustainable competitiveness, SWOT, the house model, training

\section{Introduction}

Indonesia Fisheries Industry has huge potential to growth. According to Ministry of Marine and Fisheries (2015), the national production has increased since 2003 to 2013 (KKP, 2015). In cultivation fishery, the production has shown a significant increase. Compared with capturing fishery, the increasing number production of cultivation fishery is still the largest between them, even capturing fishery has an upward trend in overall year by year. Indonesian fishery production volumes can be seen in Figure 1.

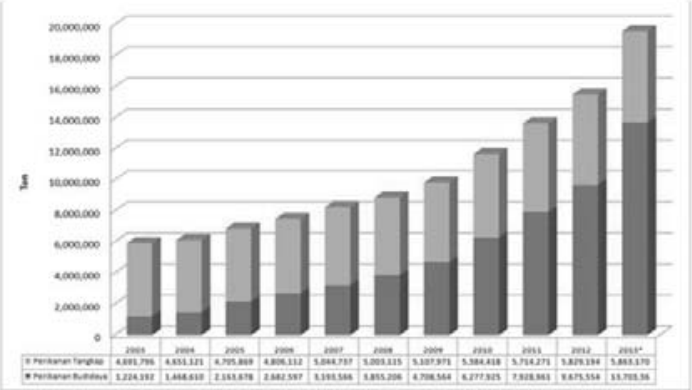

Figure 1. Indonesian Fishery Production Volumes

Source: Ministry of Marine and Fisheries, 2015 
Based on Figure 1, it appears that there were significant increases in the volume of cultivation fishery products with $1,224,192$ tons in 2003 and rose to 13.70336 million tons in 2013. This means the productions has increase 10 times higher than the productions of ten years earlier. Similar with cultivation fisheries, the volume of capture fisheries in 2003 amounted to 4,691,796 tons and boost to 5.86317 million tons in 2013. On the other hand, the increased production volumes of wild fishery are still not optimal when compared to the increase in volume that occurs in cultivation fisheries.

Following the Ministry of National Planning and Development (Bappenas) Statement in 2013, Indonesia has not been optimally utilized their potential in marine sector which have large proportion around $70 \%$ of Indonesia area. Fishery potential resource has not developed optimally based from the legal amount of allowable catch of 5.8 million tons/year, and was exacerbated by the presence of foreign fishing boats that illegally entered the marine areas of Indonesia. Biodiversity potential for economical utilization (bio-prospect and marine tourism) also has not been developed well. Coastal communities and small islands are still poor and have lack access to adequate their basic services and basic needs. They also still find difficulties to obtain economic opportunities and human resources development in marine science and technology, such as increasing the quality and quantity of marine human resources, good education and training institutions, as well as with innovation and socialization of appropriate marine science and technology which have not been optimally implemented.

According to (Djari, 2009), despite this country have huge potential in marine and fisheries industry as well as with many regions depend heavily on this sector, the lack of quality in human resources is the major problem in this industry. The development of human resource in maritime and fisheries would have a strategic role in supporting the development of marine and fisheries industry as a whole. The strategic role can be implemented through education, training and counseling which are directed to encourage and accelerate the capacity building of human resources of marine and fisheries. Through the implementation of these activities, human resources in marine and fisheries are expected to have competence and competitive capacity in order to optimize marine and fisheries development.

According to Ministry of Cooperation and Small Medium Enterprise in 2015, the number of entrepreneurs in Indonesia has only reached $1.65 \%$ of the population, therefore Indonesia competitiveness is still lagging behind to its neighbor such as Malaysia, Thailand and Singapore which has been reached over $4 \%$. The percentages of entrepreneurs in Singapore are 7\%, following by Malaysia with $5 \%$ and Thailand $4 \%$ from their population.

The Global Entrepreneurship Index (GEI) provides a detailed look at the entrepreneurial ecosystem of nations by combining individual data with institutional components. The purpose of this index is to measure the quality and the scale of the entrepreneurial process in 130 countries around the world. Indonesia ranks is 120 out of 130 countries in terms of entrepreneurial ecosystem health and this situation has been decreased 20 points from 2014 and also categorized in Tenth Biggest Decline in GEI Score between 2014-2015 (Global Entrepreneurship and Development Index, 2015). Indonesian GEl assessment results for all pillars assessment can be seen in Figure 2

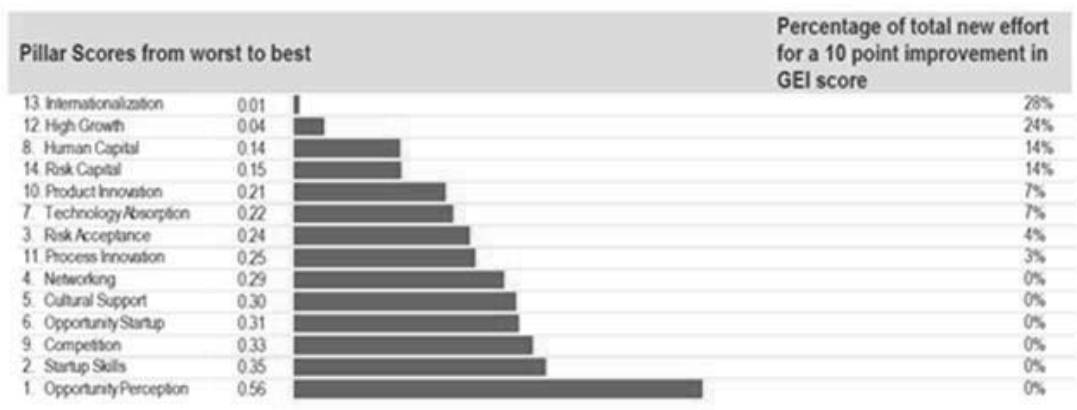

Figure 2. GEI Scores of Indonesia

Source: Global Entrepreneurship and Development Index, 2015

Figure 2 shows the score of Indonesia based on GEI. From the fourteen pillars of assessment, there are three major problems that Indonesia faces, which are internationalization, high growth, and human capital. Human capital is one of the key points in the entrepreneurial abilities assessment (ABT) sub-index is principally concerned with measuring some important characteristics of the entrepreneur and the start-ups with high growth potential. In ABT sub-index, human 
capital has the lowest value with 0.14 points. Thus requiring particular attention through training models to create sustainable competitiveness for employee especially in maritime and fisheries sector that has enormous potential in creating many entrepreneurs in Indonesia.

\section{Literature Review}

The definition of a social entrepreneur still has many debates between experts and academics today. Some definitions of social entrepreneurs which have been put forward by experts can be seen in Table 1.

Table 1. Definition of Social Entrepreneur

\begin{tabular}{|l|l|}
\hline Author (Year) & Definition \\
\hline $\begin{array}{l}\text { Mort, Weerawardena, and } \\
\text { Carniege (2003) }\end{array}$ & $\begin{array}{l}\text { Social entrepreneurs are those which are driven by a social mission to create higher social value } \\
\text { than their competitors which have produced good entrepreneurially behavior. }\end{array}$ \\
\hline Roberts \& Woods (2005) & $\begin{array}{l}\text { Social entrepreneurship is development, evaluation, and pursuing opportunities for transformative } \\
\text { social change which undertaken by visionary, energetic dedicated individuals. }\end{array}$ \\
\hline $\begin{array}{l}\text { Tan, W.L, William, J, \& Tan, } \\
\text { T.M. (2005) }\end{array}$ & $\begin{array}{l}\text { Sociopreneurship is an entrepreneurship which uses social approach as the basis. Social } \\
\text { entrepreneurship is entrepreneurship which have more intention to meet the public interest demand } \\
\text { rather than maximize the profit. Social entrepreneurship also can be called as social purpose } \\
\text { business organization }\end{array}$ \\
\hline Korosec\& Berman (2006) & $\begin{array}{l}\text { Individuals or private organizations which took the initiative to identify and resolve the social } \\
\text { problems that is important in their community. They showed the vision, energy, and ability to } \\
\text { develop new ways of reducing social problems. }\end{array}$ \\
\hline $\begin{array}{l}\text { Austin, J.,Stephenson, H.,\& } \\
\text { Wei-Skillern,J. (2006) }\end{array}$ & $\begin{array}{l}\text { Social entrepreneur are an innovation, the social value creation activities which could occur inside } \\
\text { or outside the non-profit, business or government sector }\end{array}$ \\
\hline Raghavan (2012) & $\begin{array}{l}\text { Sociopreneurs can be defined as an individual self-motivation and self-propelled with social } \\
\text { awareness and social commitment to fulfill social needs or recover a social disease by applying the } \\
\text { principles of creativity, innovation and experimentation with volunteerism as main driving force }\end{array}$ \\
\hline Glover (2012) & $\begin{array}{l}\text { Social entrepreneurs are agents of change that assist the organization with social objectives and } \\
\text { creates opportunities for organizations to achieve their social objectives }\end{array}$ \\
\hline
\end{tabular}

Dobele (2011), in his research explained external and internal factors that influence the development of social entrepreneurship in Latvia. External factors are the opportunities and threats from outside the business which cannot controlled directly, such as legal and political factors, the value of cultural, economic and technological factors, etc. Internal factors are strengths and weaknesses of the business. More can be seen in Figure 3.

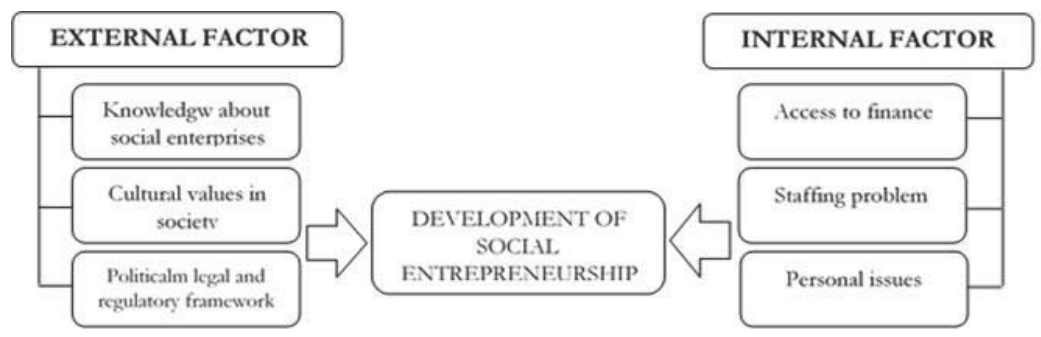

Figure 3. Factors influencing the development of social entrepreneurship (Dobele, 2011)

According to Dobele (2011), the first external factor is the knowledge about social enterprises. Issues faced include the lack of understanding of social entrepreneurship as a term. Even some entrepreneurs who actually act as social entrepreneurs sometimes did not recognize that they are social entrepreneurs. The second factor is cultural values in society. The third factor is social entrepreneurship is influenced by political and legal framework. The fourth factor is the problems with access to finance and investment. The fifth factor can occur related with recruiting and retaining staff. Last is the presence of some personal issues such as a personal challenge for social entrepreneurs to growing their businesses.

Conduct of the social entrepreneurships research in marine and fisheries cannot be separated with Independent 
Training Center of Marine and Fisheries/Pusat Pelatihan Mandiri Kelautan dan Perikanan (P2MKP). Training is one of the most common methods that usually used to improve the productivity of individuals and communicate the objectives of the organization to new employee which involves the acquisition of knowledge, the skills sharpen, concepts, rules, or changes in attitude and behavior in order to improve the performance (Rashid \& Jusoff, 2010). P2MKP is a training institution/internships center that related with maritime affairs and fisheries. P2MKP established and managed by the main actors in Indonesia maritime affairs and fisheries, both individuals and groups. P2MKP is a manifestation of participation and community self-reliance to take part in developing human resources through training of, by and for people. The main participants are the fish farmers, processors of fishery products, and fishermen who really urgently need to improve their quality through training. There are six units of Technical Implementation Unit (UPT) training which spread in Medan, Subang, Tegal, Banyuwangi, Bitung, and Ambon. However, the current number of facilities of UPT is not proportional comparing to the amount of main actors which need to be trained in estimated 6 million people. Pursuant to this, SDMKP Development Board through the Training Center of Marine and Fisheries has encouraged to add and give more support more to establish and develop the number of new P2MKP.

The establishment and development of P2MKP is an effort by the government to improve the institutional status of major actors the capabilities and self-reliance in marine and fisheries sector in order to provide adequate training which already exists. Through the establishment of P2MKP, informal training institutions can become more professional training institution and operate more efficiently in line with the rise of their legal institutional status and role for society.

P2MKP role is needed in order to (a) increase the effectiveness and efficiency of training in Minapolitan region that includes the number of 47,000 people in 2011 to 2014, and also to cover up the in ability of UPT Training Center which only consists with six units; (b) increase the training target achievement of Ministry of Marine and Fisheries through targeted training people in P2MK and (c) as a form of guidance for social entrepreneurship training institution in maritime affairs and fisheries.

According to (Foraaunet, 2009) has examined how Fisheries and Oceans Canada Pacific Region can use a competency-based management (CBM) to develop the management capacity in present and future as knowledge-based workforce. Competency frameworks seriously consider the policies, procedures, and regulations to ensure the zero conflict between CBM implementers and other HR systems such as recruitment, selection, performance management, and development.

Dalam rangka mencapai tingkat keberhasilan, beberapa faktor utama yang perlu diperhatikan dalam sebuah cluster perikanan (Yusuf \& Trondsen, 2013) adalah (1) Sumber daya manusia harus handal dan mampu mempertahankan keberlanjutan sumber daya alam, kualitas sumber daya manusia perlu dipersiapkan melalui berbagai program dan pelatihan dalam rangkamenciptakan sumber produktif dan kreatiftenaga kerja. (2) Inovasi, R \& D dan nilai rantai, inovasi adalah ketika ide atau objek dianggap baru oleh individu atau adopsi kelompok $R$ \& $D$ untuk sektor perikanan dan kelautan terkait dengan penilaian dan penelitian yang bisa menghasilkan terobosan dari kualitas yang lebih baik dan lebih murah.

In 2013, Joseph \& Trondsen has mentioned the several key factors in cluster of fisheries: (1) The human resources must be reliable and able to maintain the sustainability of natural resources. The human resources quality should enhance through a variety of programs and training in order to create a source of productive and creative labor. (2) Innovation, $R$ \& $D$ and the value chain. Innovation is happen when an idea or object considered as a new thing by the individual or the adoption group. $\mathrm{R} \& \mathrm{D}$ for marine and fisheries sector are closely related with assessment and research that could generate a breakthrough of cheaper option and better quality. (3) Market orientation, partnerships, and networks. Market orientation should be consistent with the vision of the country in order to create competitive advantage in global competition. Creating partnerships and networks which marked by cooperation among institutions (government and employers) is the foundation to realize harmonization and working methods of entire system. The decision to develop cluster of fisheries must be based on combination of various factors that would affect the availability of resources (raw materials), transport facilities, supporting infrastructure, availability of labor, the structure of the environment, information access and integrated marketing. 


\section{Research Methods}

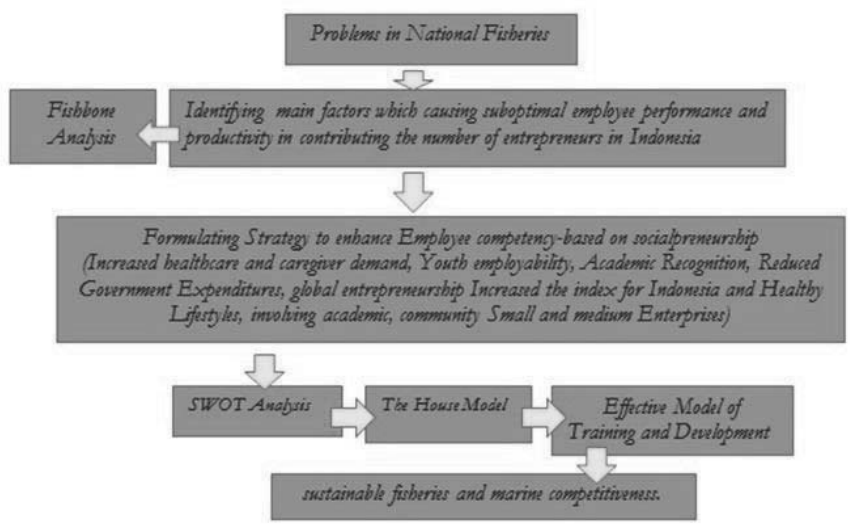

Figure 4. Research Framework

\subsection{Fishbone Analysis}

A causal diagram (Fishbone) is a graphic illustration that connects between outcomes and causes problems (Ishikawa, 1985 in Rampersad 2001). Fishbone diagram is used to analyze the causal relationships and amenities to search real solution for the problems, the diagram can be seen in Figure 5.

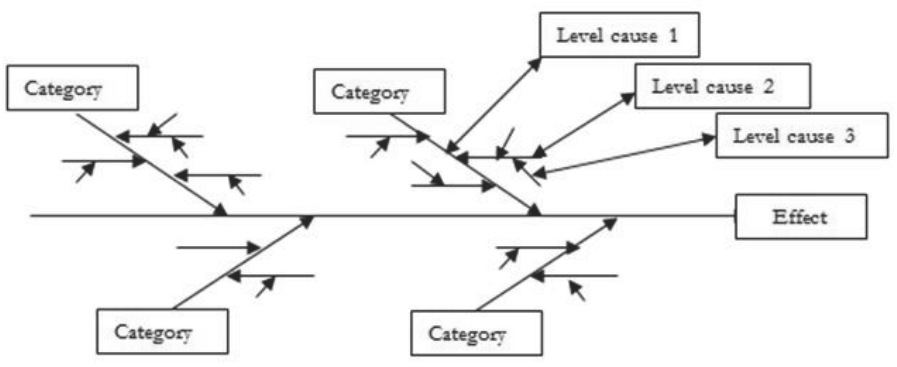

Figure 5. Fishbone Diagram (Rampersad, 2001)

\subsection{SWOT Analysis}

According to Rangkuti (2003), the Environment organization or company is divided into two, the internal environment and the external environment. The internal environment consists of strength and weakness. Whereas external environments are compose of the opportunities and threats. In determining of indicators, it takes strategy objectives concerning the combination of strengths-opportunities, weaknesses-opportunities, strengths-threats, and weaknesses- threats that subsequently formed in the matrix.

\subsection{The House Model}

The House Model is a tool which is used by an organization using a concept built to transform a dream into an action. Figure 6 will explained The House Model. 


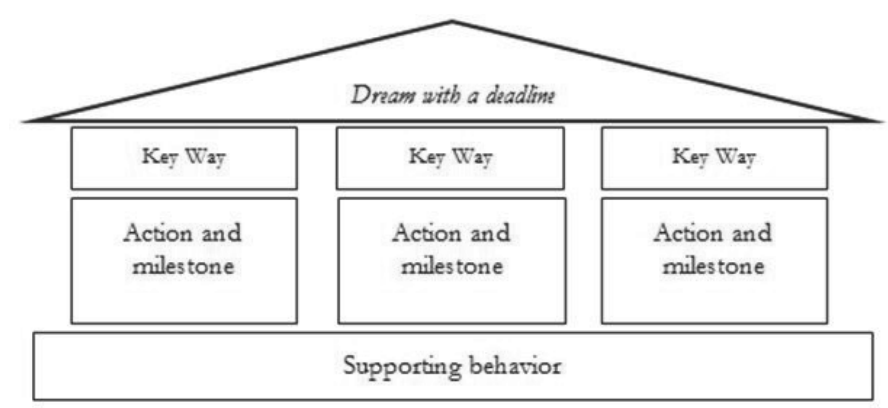

Figures 6. The House Model Framework (Horovitz dan Corbooz, 2007)

According to Horovitz and Corbooz (2007), there are three components to build good visions which dreams located as the rooftop, pillar consists as the main methods to achieve this vision, and the foundation as the main indicators of improved performance and the behavior of supporting factors.

\section{Results and Discussions}

Employments play strategic role and occupy a central position in enhancing the productivity and performance of a processing industry, including fish processing. Considering their role of and function as a value creator, company should realize employment is a company's foremost and most valuable asset. Furthermore, diversification of processed products and the development of technology benefits are also imperative to make industry able to always deliver products that follow the dynamics changes of market demand. (Arthajaya, 2008).

According to Ministry of Marine and Fisheries (2010), labor absorption in the fisheries sector is divided into the activities of capture fisheries, cultivation fishery, processing and marketing, and other supporting services which include manpower involved in fisheries sector development programs. Conditions and employment issues in Indonesia are generally due to differentiation between the qualities and the actual required by business, which can lead to the occurrence of unemployment and low productivity. The gap occurs because of education and training offers are supply driven characteristic and not based on job competencies. (Arthajaya, 2008).

Poor quality of human resources in fisheries sector is becomes a barrier of development. Aswanah, et. al. (2013) describes in implementation phase of Minapolitan fisheries development programs is not running as appropriate as actual plan. The several factors which constraint this program are still occurring such as the low quality of fishermen, the fishery resources at Java Sea has experienced over fishing, the shortage of funds, lack of functioning auctions at TPI, a lack of coordination between government and society. One way that is considered as effective way to improving the quality of human resources is by do massive and intensive counseling. Unfortunately, mostly the fisheries socialization system under decentralization era in Indonesia is in less sustainable conditions (Djari, 2009).

In general, the condition of human resources quality in fisheries sector are (1) relatively low level of education, (2) relatively low in empowerment and productivity, (3) entrepreneur mindset usually started when going to retire (4) poor motivation and competitiveness, and (5) lack of work ethic culture, (6) less commitment from owners and managers of the organization/management to improve the quality of human resources and (7) trainings conducted were not based on outcomes.

There are two main causes of obstacle in developing Human Resources of Indonesian fisheries competency models in order to increase the contribution number of Indonesian entrepreneurs, namely internal factor and external factor. The main cause of internal factor is the mindset to work as an employee to pursue peak career is the highest convenience actualization of human satisfaction which does not have an impact on social welfare. On the other hand, the main cause external factors lies in the competence development model which is targeting to create entrepreneur in fisheries sector has not been made based on outcomes and is worsened by the absence of continuous monitoring. 


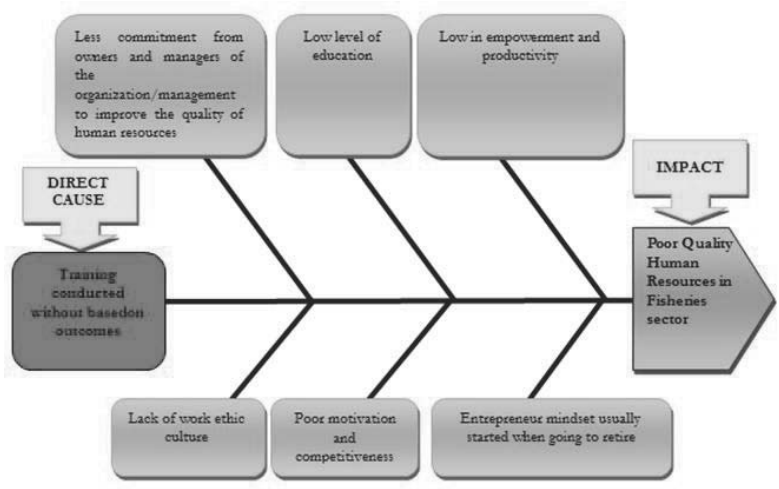

Figure 7. The Constraints of Low Human Resources Performance in Fisheries Sector Next will be discussed through a SWOT analysis as follows in Table 2

Table 2. SWOT Analysis

\begin{tabular}{|c|c|c|}
\hline External Analysis & $\begin{array}{l}\text { Strengths } \mathbf{( S ) :} \\
\text { a. Fisheries sector have excellent commodities } \\
\text { both regional and national } \\
\text { b. High product quality } \\
\text { c. The approach methods for products } \\
\text { promotion }\end{array}$ & $\begin{array}{l}\text { Weakness (W): } \\
\text { a. Poor quality of human resources in } \\
\text { fisheries industry } \\
\text { b. Low number of entrepreneurs in fisheries } \\
\text { sector } \\
\text { c. Limited access to market information } \\
\text { d. Limited marketing access of fishery } \\
\text { products both fresh and processed } \\
\text { e. Partnerships with companies still limited } \\
\text { and not running well } \\
\text { f. Competent human resources in fisheries } \\
\text { is very few to enhancing the } \\
\text { competitiveness of fishery products } \\
\text { g. Results of the research is not } \\
\text { implemented continuously, only to the } \\
\text { extent as a report } \\
\text { h. Training activities which not based on } \\
\text { fisheries sector outcome }\end{array}$ \\
\hline $\begin{array}{l}\text { Opportunities (0): } \\
\begin{array}{cl}\text { a. } & \text { The opportunities from market demand of certain } \\
\text { b. } & \text { Have export potential as source of country foreign } \\
\text { income } & \\
\text { c. } & \text { The support of national and local governments }\end{array}\end{array}$ & $\begin{array}{l}\text { S-O Strategy: } \\
\text { a. An increase of productivity level in fisheries } \\
\text { sector with human resources monitoring } \\
\text { and continuous evaluation } \\
\text { b. The development of processing business } \\
\text { with value added products and } \\
\text { competitiveness strategy }\end{array}$ & $\begin{array}{l}\text { W-O Strategy: } \\
\text { a. Improving the products quality that meets } \\
\text { the international standards } \\
\text { b. Expansion the continuous business } \\
\text { partnership network with contract law } \\
\text { system-based } \\
\text { c. Improving the Institutional capability of } \\
\text { fisheries main actors } \\
\text { d. Increasing the competencies through } \\
\text { training and coaching in order to } \\
\text { increase independence and well-being of } \\
\text { the fisheries sector actors } \\
\text { e. Make regulation related with contract } \\
\text { system of activists fisheries partnership } \\
\text { contract }\end{array}$ \\
\hline Threats (T): & S-T Strategy: & W-T Strategy: \\
\hline $\begin{array}{l}\text { a. Free Trade Agreement ASEAN-China Free Trade } \\
\text { Agreement (ACFTA) will have impact on increasing } \\
\text { numbers of import product and the } 2015 \text { ASEAN } \\
\text { Economic Community (AEC). } \\
\text { b. Fluctuation price } \\
\text { c. Environmental issue that demanding of fisheries } \\
\text { methods development based on environmental } \\
\text { d. The Competition level among companies in fisheries } \\
\text { industry is getting higher. } \\
\text { e. Brain drain issues in labor compensation system of } \\
\text { fisheries sector }\end{array}$ & $\begin{array}{l}\text { a. Improving the products quality that meets } \\
\text { the export standards } \\
\text { b. Synergize the cooperation of ABGC } \\
\text { (Academic, Business, Government, } \\
\text { Community) in order to enhance fishery } \\
\text { product competitiveness } \\
\text { c. Developing the fish processing business } \\
\text { and marine tourism as an alternative } \\
\text { livelihood }\end{array}$ & $\begin{array}{l}\text { a. Market expansion and provide the access } \\
\text { of market information for all actors in } \\
\text { fishery toward domestic and international } \\
\text { markets } \\
\text { b. Establish a continuous business } \\
\text { partnerships with contract law system- } \\
\text { based } \\
\text { c. The limiting imports of fishery products } \\
\text { policy } \\
\text { d. The improvement of compensation } \\
\text { system for local/domestic fisheries } \\
\text { industry }\end{array}$ \\
\hline
\end{tabular}


Based on the SWOT analysis, we can select best strategies to improve the quality of human resources in fisheries sector, which are by improving the competencies through training and coaching in order to increase the independence and wellbeing of the fisheries sector players, and then followed by design the house model concept with based on formulation strategies resulting in SWOT analysis. Fourteen strategies has extracted from SWOT analysis. These strategies then analyzed and grouped into three pillars based on aspects of Preparation, Implementation and Impact with the foundation of regulation and policy. Dream to be achieved are a model design of training and development based on socialpreneurship. The House Model of this research can be seen in Figure 8.

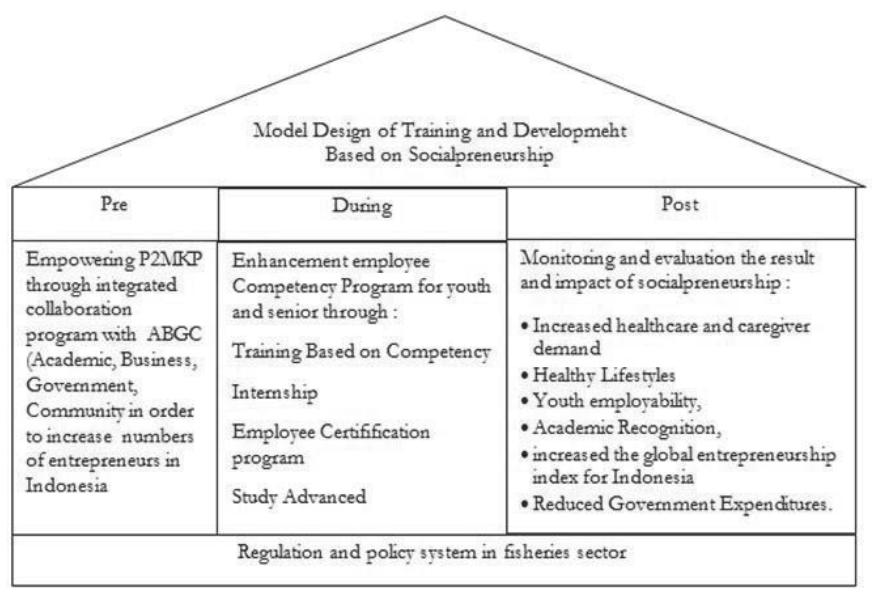

Figure 8. The House Model of Model Design of Training and Development Based on Socialpreneurship

The strategy to enhance human resources competency-based socialpreneurship through the pillars the house models are to produce desired outcomes are: Increased demand healthcare and caregiver, Youth employability, Academic Recognition, Reduced Government Expenditures, global entrepreneurship Increased the index for Indonesia and Healthy Lifestyles which involve the contribution of academic society, community and Small Medium Enterprises Medium in terms of optimizing the role of P2MKP through survey activity, module shaping and training that are continuously evaluated.

\section{Conclusions}

1. There are two main factors causing suboptimal model of developing competency of employee in the field of fisheries which consists of internal factors which are related to the mindset of employee to pursue a career as the highest comfort zone and work satisfaction but specifically did not have an impact on social welfare, on the other hand the main external factors caused by supervision model of training and development in order to create employee competency is not based on outcome also without continuous improvement in monitoring and evaluation.

2. The best Strategy to enhance competence-based on socialpreneurship pillar through the house model is formulating training and development which has the following outcomes: Increased healthcare and caregiver demand, Youth employability, Academic Recognition, Reduced Government Expenditures, global entrepreneurship Increased the index for Indonesia and Healthy Lifestyles, involving academic, community Small and medium Enterprises in order to optimizing the strategic role function of Pusat Pelatihan Mandiri Kelautan dan Perikanan (P2MKP) through survey activity, shaping and training modules which are evaluated in an ongoing basis.

\section{References}

Acs, Z. J., Szerb, L., \&Autio, E. (2015). The Global Entrepreneurship and Development Index. Cheltnam: Edward Elgar.

Aswanah, Y. K., Efani, A., \& Tjahjono, A. (2013). Evaluasi terhadap Implementasi Program Pengembangan Kawasan Minapolitan Perikanan Tangkap di Pelabuhan Perikanan Nusantara (PPN) Brondong Kabupaten Lamongan Jawa Timur (Evaluation in The 
Implementation of Regional Minapolitan Program Development in Brondong Fishing Port at Lamongan East Java). Jurnal ECSOFiM, 1(1), 97-108.

Austin, J. E., Stevenson, H., \& Wei-Skillern, (2006). Social and commercial entrepreneurship: The same,different or both? Entrepreneurship Theory and Practice, 30(1), 1-22.

Becker, G.S. (1962). Investment in Human Capital: A Theorical Analysis. The Journal of Political Economy, 7, 9-49.

Dobele, L. (2011). Influencing Factors of Social Entrepreneurship in Latvia. International Scientific Conference is the property of Latvian University of Agriculture.

Djari, A.A. (2009). Pengembangan Sistem Penyuluhan PerikananEra Desentralisasi di Indonesia (Systems Development of Fisheries Extensionon Decentralize Circumstance in Indonesia) (Doctoral dissertation, Bogor Agricultural University). Available from IPB Repository.

Foraaunet, A. G. M. (2009). Building People Management Capacity Through Competency-Based Management In Fisheries And Oceans Canada, Pacific Region (Master Thesis, Royal Roads University). Available from ProQuest Dissertations and Thesis database.

Glover, Y.D. (2012). Organization Development and Social Entrepreneurship: Do Well By Doing Good. American Journal of Management, 12(2/3), 117-122.

Gumilar, I. (2010). Metode Riset untuk Bisnis dan Manajemen. Jakarta: Utama.

Horovitz J, \& Ohlsson-Corboz. (2007). A Dream with a Deadline: Turning Strategy into Action. Harlow: FT Prentice Hall.

Mort, G.S., Weerawardena, J. \& Carnegie, K. (2003). Social entrepreneurship: Towards conceptualization. International Journal of Nonprofit and Voluntary Sector Marketing, 8(1), 76-88.

Korosec, R.L \& Berman, E.M. (2006). Municipal support for social entrepreneurship. Public Administration Review, (May/June), 448-462.

Raghavan, B.S. (2012, June 19). Boosting sociopreneurship in India. Kasturi and Sons Ltd. Retrieved from http://search.proquest.com/ docview/1321739452?accountid=3

Rampersad, H. (2001). Total Quality Mangement: an executive guide to continuous improvement. Berlin: Heidelberg.

Rangkuti, F. (2003). Analisa SWOT Teknik Membedah Kasus Bisnis (SWOT Analysis Techniques Dissecting the Business Case). Jakarta: Gramedia Pustaka Utama.

Rashid, K.M, \& Jusoff, K. (2010). The Determinants of Training Effectiveness inMalaysian Organizations. Interdisciplinary Journal of Contemporary Research in Business, 2(2), 66-77.

Roberts, D. \& Woods, C. (2005). Changing the world on a shoestring: The concept of social entrepreneurship. University of Auck.

Sudarno. (2012). Kontribusi Usaha Mikro, Kecil, dan Menengah (UMKM) dalam Penyerapan Tenaga Kerja (The Contribution of Micro, Small Medium Entreprise's (SME's) in employment). Penelitian dan Pengembangan Humanoria, 9, 68-76.

Tambunan, T. (2012). Pasar Bebas ASEAN: Peluang, Tantangan, dan Ancaman bagi UMKM Indonesia (ASEAN Free Market: Opportunity, Challenge, and threat for Indonesia SME's). Infokop, 21, 13-35.

Tan, W. L., William, J., \& Tan, T.M. (2005). Defining the social in socialentrepreneurship: Altruism and Entrepreneurship. International Entrepreneurship and Management Journal, 1, 353-365. doi:10.1007/s11365-005-2600-x

Umar, H. (1996). Metode Penelitian untuk Skripsi dan Tesis Bisnis (Research Method for Business Essay and Thesis). Jakarta: PT. Raja GrafindoPersada.

Yusuf, M., \& Trondsen, T. (2013). Improving Indonesia's Competitiveness: Innovation,Value Chains And Cluster-Bases For Realising The Huge Potential Of Marine And Fisheries. The International Journal of Organizational Innovation, 6(1), 111-118.

Zuhal. (2010). Knowledge and Innovation: Platform Kekuatan Daya Saing (Knowledge and Innovation: The Power of Copetitiveness Platform). Jakarta: Gramedia Pustaka Utama. 